\title{
AvaILABILITY OF ChILDHOOd SOCIAL SERVICES IN LePROSY SettlementS IN SOUTHERN Nigeria
}

\author{
E. Enwereji, R. Ekeh and K. O. Enwereji
}

Department of Community Medicine, College of Medicine, Abia State University Teaching Hospital, Uturu, Abia State, Nigeria

Reprint requests to: Dr. E. Enwereji, P. O. Box 12319, Umungasi, Aba, Abia State, Nigeria.

E-mail: hersng@yahoo.com

\begin{abstract}
Background: Children of leprosy patients deserve social services such as free education, health care services including HIV/AIDS prevention like others. The extent to which these children benefit from such services is not clear. One expects that since they are exposed to health hazards in settlements that they would benefit immensely from preventive health care and other services. Study investigates the extent to which such services are available to them.

Methods: Study was carried out in 3 purposively selected leprosy settlements, Uzuakoli in Abia State, Ohaozara in Ebonyi State and Ogbomoso in Oyo State using 86 children from 10 years and above who are available during study. Structured questionnaire and interview schedule were instruments used. Data were analyzed with Stat Pac Gold package.

Results: Provision of social services to children of leprosy patients studied is limited. Only 13(16.5\%) of the children said their parents did not pay school fees. The rest paid. However, despite payment of fees, higher proportion of children in Abia State 43(95.6\%) more than in Oyo State 36(87.9\%) went to school $P=.03$. About $42(97.7 \%)$ of children in Abia State and 30(83.3\%) in Oyo State lack knowledge of HIV prevention. Neither reproductive health services including HIV/AIDS prevention nor prophylactic treatments are available to them.

Conclusion: In view of above results, increased social services including HIV/AIDS prevention, prophylactic treatments and health promotions are recommended.
\end{abstract}

Key words: leprosy, children, HIV/AIDS, sex education, immunization, Nigeria

\footnotetext{
Résumé

Contexte: Les enfants de patients lépreux méritent des services sociaux tels que l'éducation gratuite, les services de santé incluant la prévention du VIH/SIDA et autres pathologies. L'importance du bénéfice tiré de ces services par ces enfants n'est pas claire. On s'attend à ce que vu leur exposition aux risques sanitaires dans les villages, ils bénéficient immensément des services de santé et autres. Des études évaluent dans quelles mesures ces services sont disponibles pour eux.

Méthode: L'étude a été menée dans trois léproserie sélectionnées: Uzuakoli dans l'état d'Abia, Ohaozara dans l'état d'Ebonyi State et Ogbomoso dans l'état d'Oyo avec recrutement de 86 enfants, âgés de 10 ans ou plus et qui sont disponibles au cours de la période d'étude. Les instruments utilisés étaient un questionnaire structuré et des entretiens programmés. Les données ont été analysées à l'aide du logiciel Stat Pac Gold.

Résultats: La disponibilité des services sociaux pour les enfants de patients lépreux au cours de cette étude est limitée. Seulement $13(16,5 \%)$ ont affirmés que leurs parents ne payaient pas de frais scolaires. Les autres paient. Cependant, malgré le paiement des frais, une importante population d'enfants dans l'état d'Abia $43(95,6 \%)$ plus que dans l'état d'Oyo $36(87,9 \%)$ allaient à l'école $(p=0,03)$.
} 
Environ 42 (97,7\%) des enfants dans l'état d'Abia et 30(83,3\%) dans l'état d'Oyo manquent de connaissance sur la prévention du VIH. Aucun service de santé de la reproduction incluant la prévention du VIH/SIDA ni les traitements prophylactiques ne sont disponibles pour eux.

Conclusion: Au vu des résultats ci dessus, il est recommandé de renforcer les services sociaux incluant la prévention du VIH/SIDA, les traitements prophylactiques et la promotion de la santé.

Mots clés: Léproserie, enfants, VIH/SIDA, éducation sexuelle, vaccination, Nigeria

\section{Introduction}

The core function of governments is to provide social services including health care services to its citizens irrespective of social status. Yet many governments selectively deliver these basic services. ${ }^{1,2}$ They expose children of leprosy patients to poor environmental conditions including social integration with others. ${ }^{3}$

Other studies ${ }^{4,5}$ specifically noted that though various organization, like world health organization, German leprosy Relief Association, international Christian crusaders foundation, Damien Foundation, Methodist Mission, Assemblies of God Mission, British leprosy Organization, Federal and State government of Nigeria have for years provided material and human resources to the settlements in Abia, Ebony, and Oyo States, yet little or no information is available on the extent to which children of leprosy patients benefit from these services. Studies ${ }^{6-8}$ stress that prejudice that children of leprosy patients harbour mycobacterium leprae like their parents result to isolation and encourage their exclusion from most social services. There is widespread discrimination and rejection of children of leprosy patients in employment agencies, ${ }^{9-11}$ in marriage ${ }^{12-14}$ and in schools. ${ }^{15-18}$

There is therefore the need to appraise the social services available to children of leprosy patients in leprosy settlements in Nigeria to reduce the tendency of excluding them from welfare planning services. Belief that children of leprosy patients, like other children, should benefit from health care prevention programmes and other social services motivated the authors to carry out this study.

The study documents available social services to children of leprosy patients and the extent to which they benefit from such programmes, including reproductive health and immunizations services. The question is, do health care providers and others discriminate against children of leprosy patients in settlements? To what extent do the governments' (Local, State and Federal) welfare services target these children?

\section{Materials and Methods}

Nigeria has 6 zones. Each zone has at least a leprosy settlement. This descriptive study investigated types of services extended to children of leprosy patients in leprosy settlements in 2 zones of Nigeria (South East and South West zones). Three purposively selected leprosy settlements in Abia, Ebonyi and Oyo State of Nigeria were studied. These settlements were chosen for study because they are the only leprosy settlements in these zones with inmates. Inmates in the other leprosy settlements (leprosy patients and their children) have deserted the settlements and have taken to street begging on the streets.

A sample of 86 children of leprosy patients 10 years and above, who are resident in the 3 settlements were purposively chosen for study. These are the total number of children who are available at the time of study and who are also capable of providing needed information. This is made up of 40 children in Uzuakoli, 5 in Ohaozara and 41 in Ogbomoso leprosy settlements. Due to the few number of children, 5 in Ahaozara in Ebonyi State, data from this settlement were analyzed together with those in Uzuakoli in Abia State. The analyses in these two States were merged because Ohaozara and Uzuakoli have same cultural background. Ohaozara was part of Abia State before the creation of Ebonyi State. In this analysis, settlements are interchanged with the states where they are sited.

Structured questionnaire and interview guide were used to collect information from the children. For uniformity in the responses, the questions were administered. A good number of the respondents could not read and write. Information collected included: health services available to the children, career goals, extra curricula activities, educational opportunities, reasons for continued stay in the settlements and others.

Data were entered and analyzed wth computer. Stat Pac Gold package was used in the analysis. Percentages, Chi square and others at 0.05 significant value were the statitics used in the analysis. Also responses from focus group discussion were translated and transcribed.

\section{Ethical considerations}

To carry out this survey, written approvals were got from the Leprologists in charge of the settlements in Ministry of Health in Abia, Ebonyi and Oyo States. To obtain information from the children of leprosy patients, the consents of the health workers in the settlements as well as that of the leprosy patients themselves was obtained. 


\section{Results}

Socio-demographic characteristics of the children

The children studied were made up of 23 males and 18 females in Oyo State and 30 males and 15 females in Abia State who were within the ages of 10 to 27 years. The mean age of the children in Oyo State was 14.7 years \pm 4.1 while that for those in Abia State was 12.3 years \pm 2.2 showing that the children of leprosy patients in Oyo State were older than those in Abia State $P=.001$.

More than half of the children studied, 27(65.9\%) in Oyo State and $25(55.6 \%)$ in Abia State were born in the settlements. The rest were born outside the settlements. Also more than half of the children in Oyo State $23(56.1 \%)$ and $22(48.9 \%)$ in Abia State live with their parents while the rest live with other relations and friends.

\section{Schooling of children of leprosy patients}

Finding shows that except for Uzuakoli settlement in Abia State, where a primary school is sited in the settlement, other settlements do not have schools located in them. Children of leprosy patients in these settlements cover between 7 to $18 \mathrm{~km}$ daily to attend school. Locating a school inside the settlement influenced rate of schooling as evidenced by the fact that more children in Abia State, 43(95.6\%), than in Oyo State $36(87.9 \%)$, were in primary, secondary or post-secondary $P=.005$. Out of the 7 children who were not in school in both states, $3(42.8 \%)$ were not in school because their parents could not afford school fees, while $4(57.2 \%)$ were because of lack of interest.

Further finding shows that a good number of the children of leprosy patients do not enjoy free education as high as $66(83.5 \%)$ of the children in both States paid school fees. Only $13(16.5 \%)$ of the children indicated that they were on free education, but this was at the instance of the donor Agencies (German Leprosy Foundation and Damien Foundation) as shown in Table 1.

Out of $43(95.6 \%)$ children who were in school in Abia State, and $36(87.9 \%)$ in Oyo State, only $13(30.2 \%)$ in Abia State and 16(44.4\%) in Oyo State attended school regularly (at least 4 times a week) during the period of the study. Some of the reasons the children had for not attending school regularly included having to walk long distances between settlements and school, being unable to pay school fees and lack of time as a result of engaging in several extracurricular activities in Table 2. The main reason the children 22(53.7\%) in Oyo State had for not attending school was that they were engaged in farming, while in Abia State the main reason $28(62.2 \%)$ had was that they were occupied with poultry keeping.
Social integration of children of leprosy patients with others in school

A significant proportion of the children in Abia State 42(93.3\%) more than those in Oyo State 30(73.2\%) enjoyed cordial relationship with others in school $\mathrm{X}^{2}=11 P=.003$ (Table 3).

\section{Extracurricular activities}

The types of extracurricular activities the children of leprosy patients participated in with others were further used to examine the extent to which they are accepted. The finding shows that majority of the children $32(78.1 \%)$ in Oyo State and $42(93.3 \%)$ in Abia State participated in activities such as footballing, net-balling, dancing competition, track race, debating and religious activities. Only $3(8.3 \%)$ of the children in Oyo State and $1(2.3 \%)$ in Abia State did not participate in any extracurricular activity because of lack of interest. Further investigation revealed that a good number of the children in the two States $82(95.4 \%)$ had in one way or the other represented others in several activities including sports.

\section{Children's desire to live outside the settlement}

Realizing the mean ages of the children of leprosy patients studied, 14.7 years \pm 4.1 in Oyo State and 12.3 years \pm 2.2 in Abia State and the number who are not infected but are cohabiting with the opposite sex without being properly married, there was need to find out their willingness to live somewhere else other than the settlements. As shown in Table 4, a good number of the children 37(90.2\%) in Oyo State and $32(71.1 \%)$ in Abia were desirous to live somewhere else other than the settlements but this desire was more on males than on females.

The reasons few of the children had for not desiring to live somewhere else was sought. From the children's responses, the main reasons they had were: loss of contact with family members, fears of rejection and separation from loved ones in the settlements.

\section{Career goals}

Realizing that the children need to live independent lives and aspire to higher goals like other children in the society, they were required to list their expected career goals in life. The response to this question was used to assess the extent to which the children of leprosy patients intend to improve their means of livelihood amidst all difficulties. From the children's responses in Table 5, the most popular profession which a good number of them 16(39.2\%) in Oyo State and $15(33.3 \%)$ in Abia State had was Medicine. This shows that the children had good career goals and aspirations. Therefore if encouraged, they possess the potentials to succeed.

Noting the children's aspirations in the settlements 
would assure policy makers in government (federal, state and local) that if these children are motivated through accessible and affordable quality education, there is every likelihood that they would succeed like others thereby contribute their quota in nation building.

\section{Provision of health care services and/or health care seeking behavior}

Provision of health care services and health care seeking behavior for the target group was generally very poor. A good number of the children, who were sick during the study, did not seek treatment. Majority of those whose parents could not pay for the cost of their treatment were lying critically ill without the intention of presenting for treatment in the clinics located in the settlements. They concentrated on self-medication provided by their parents.

Treatment even for minor ailments was not free for the children in the settlements. The parents of $26(57.8 \%)$ of the children in Abia State, and 32(78\%) in Oyo State, paid for cost of minor treatments for their children. The few parents who could not afford their children's hospital fees, settled for Agbo (herbal concoctions) and/or purchase of drugs from patent medicine stores.

\section{Health care control programmes}

Health care control programmes were limited to these children. Finding confirmed that $31(75.6 \%)$ of the children in Oyo State, and 25 (55.6\%) in Abia State lacked knowledge of HIV/AIDS prevention strategies, including methods of family planning. Furthermore, 22(53.7\%) of the children in Oyo state and $20(44.4 \%)$ in Abia State confirmed that health care workers rarely extend preventive services like family planning including HIV/AIDS control measures and national immunization services in settlements.

In terms of protecting the children against leprosy protection, the finding revealed no formal provision of prophylaxis to the children. About 20(48.8\%) of the children in Oyo and 29(64.4\%) in Abia States confirmed sharing leprosy drugs especially dapsone with their parents. But this is at the instance of their parents.

The study found that $6(6.9 \%)$ of the children studied, made up of $4(9.8 \%)$ in Oyo State and $2(4.4 \%)$ in Abia State were infected with leprosy and they were all on treatment with the clinic in the settlement as at the time of study.

Another important finding is the rate at which the female children of the leprosy patients cohabited with the opposite sex (both infected and noninfected) in the settlements. Finding showed that out of 33 female children of leprosy patients studied, $11(33.3 \%)$ of them without being properly married, were living and making babies with the opposite sex in settlements. About $4(22.2 \%)$ of them in Oyo State and $3(20 \%)$ in Abia State were pregnant while 3 $(16.7 \%)$ of others in Oyo and $1(6.7 \%)$ in Abia were nursing babies.

Table 1. Free education for children of leprosy patients by State

\begin{tabular}{llll}
\hline $\begin{array}{l}\text { Enjoyed free } \\
\text { education }\end{array}$ & Abia state (\%) & Oyo state (\%) & Both states (\%) \\
\hline No & $32(74.4)$ & $34(94.4)$ & $66(83.5)$ \\
Yes & $11(25.6)$ & $2(5.6)$ & $13(16.5)$ \\
\hline Total & $43(100)$ & $36(100)$ & $79(100)$ \\
\hline $\mathrm{X}^{2}=16.7 P=.03$ & & &
\end{tabular}

Table 2. Reasons for not attending school regularly

\begin{tabular}{llll}
\hline Reason & $\begin{array}{l}\text { Oyo state (\%) } \\
\mathbf{n = 4 1}\end{array}$ & $\begin{array}{l}\text { Abia state (\%) } \\
\mathbf{n = 4 5}\end{array}$ & Both states (\%) \\
\hline Distance to school is far & $18(43.9 \%)$ & $4(8.9 \%)$ & $22(25.6 \%)$ \\
Inability to pay school fees & $15(36.6 \%)$ & $19(42.2 \%)$ & $34(39.5 \%)$ \\
Hawking & $6(14.6 \%)$ & $4(8.9 \%)$ & $10(8.5 \%)$ \\
Farming & $22(53.7 \%)$ & $5(11.1 \%)$ & $27(22.9 \%)$ \\
Poultry keeping & $11(26.8 \%)$ & $28(62.2 \%)$ & $39(33.1 \%)$ \\
Piggery & - & $2(4.4 \%)$ & $2(1.7 \%)$ \\
Housekeeping & $16(39 \%)$ & $14(31.1 \%)$ & $30(25.4 \%)$ \\
Braiding/Barbing & - & $1(2.2 \%)$ & $1(.8 \%)$ \\
Baby seating & $6(14.6 \%)$ & $3(6.7 \%)$ & $9(7.6 \%)$ \\
\hline Total & $94(100 \%)$ & $80(100 \%)$ & $174(100.0 \%)$ \\
\hline
\end{tabular}


Table 3. Relationship between children of leprosy patients and others in school

\begin{tabular}{llll}
\hline Type of relationship & Abia state (\%) & Oyo state (\%) & Both states (\%) \\
\hline Cordial & $42(93.3)$ & $30(73.2)$ & $72(83.7)$ \\
Not cordial & $3(6.7)$ & $11(26.8)$ & $14(16.3)$ \\
\hline Total & $45(100)$ & $41(100)$ & $86(100)$ \\
\hline$X^{2}=11 P=.003$ & & &
\end{tabular}

Table 4. Children's desire to live outside the settlement

\begin{tabular}{llllll}
\hline $\begin{array}{l}\text { Desired to live } \\
\text { outside }\end{array}$ & $\begin{array}{l}\text { Abia state } \\
\text { (\%) } \\
\mathbf{n = 4 5}\end{array}$ & $\mathbf{F}$ & $\mathbf{M}$ & $\mathbf{F}$ & $\begin{array}{l}\text { Both states } \\
\text { (\%) }\end{array}$ \\
\hline & $\mathbf{M}$ & $\begin{array}{l}\mathbf{9} \text { (\%) } \\
\mathbf{n = 4 1}\end{array}$ & \\
Yes & $23(51.1)$ & $9(20)$ & $14(34.1)$ & $7(17.1)$ & $53(61.6)$ \\
No & $7(15.6)$ & $6(13.3)$ & $9(22)$ & $11(26.8)$ & $33(38.4)$ \\
\hline Total & $30(100)$ & $15(100)$ & $23(100)$ & $18(100)$ & $86(100)$ \\
\hline
\end{tabular}

Table 5. Career goals of the children of leprosy patients by settlement

\begin{tabular}{llll}
\hline $\begin{array}{l}\text { Career goals of the } \\
\text { children }\end{array}$ & Oyo state (\%) & Abia state (\%) & Both states (\%) \\
\hline Teaching & $2(4.9 \%)$ & $2(4.4 \%)$ & $4(4.7 \%)$ \\
Medicine & $16(39.2 \%)$ & $15(33.3 \%)$ & $31(36 \%)$ \\
Nursing & $6(14.6 \%)$ & $9(20 \%)$ & $15(17.4 \%)$ \\
Business & $3(7.3 \%)$ & $1(2.3 \%)$ & $4(4.7 \%)$ \\
Petty trading & $1(2.4 \%)$ & $2(4.4 \%)$ & $3(3.5 \%)$ \\
Preaching & $1(2.4 \%)$ & $3(6.8 \%)$ & $4(4.7 \%)$ \\
Engineering & $1(2.4 \%)$ & $9(20 \%)$ & $10(11.6 \%)$ \\
Law & $10(24.4 \%)$ & $2(4.4 \%)$ & $12(14 \%)$ \\
Banking & $1(2.4 \%)$ & $2(4.4 \%)$ & $3(3.5 \%)$ \\
\hline Total & $41(100 \%)$ & $45(100 \%)$ & $86(100)$ \\
\hline
\end{tabular}

\section{Discussion}

Contrary to expectations, the government (federal, state and local) provide little or no social services to children of leprosy patients in the settlements. There was limited access to preventive health care and social services like HIV/AIDS, family planning, immunization, free education and others. A good number of the children lacked knowledge of HIV/AIDS prevention strategies as well as national immunization days, confirming that such services are not available. The finding that children of leprosy patients had limited access to social services agrees with that of other reports ${ }^{13-15}$ where children of leprosy patients are excluded from most welfare programmes in the society.

Also the fact that a good number of female children of leprosy patients studied cohabited with opposite sex and were either nursing babies or pregnant shows lack of family planning services and sex education for them. It also indicates high promiscuous sex life among children of leprosy patients in settlements. The finding on high promiscuous sex life among children of leprosy patients studied, agrees with that of another report ${ }^{4}$ among children in rehabilitation institutions. This suggests the need to stress safer sex practices among the target group and the need to limit the population of mature children resident in leprosy settlements.

Not providing prophylactic treatment to children at risk of leprosy infection in settlements in this study negates WHO 1980 and 1988 recommendations ,19, 20 that individuals exposed to leprosy infection should be given prophylaxis for effective control measures. This lack of organized prophylactic treatment to children of leprosy patients in these settlements might be responsible for the $6(6.9 \%)$ of the children who were already infected with leprosy during the period of study.

Social integration is one of the services the children of leprosy patients desire to protect them against discrimination and/or rejection in the society. The association of children of leprosy patients with others both in school and elsewhere was used to note the extent to which these children are discriminated against. From the children's responses, their social integration with others was excellent. 
This was shown by the number of extracurricular activities the children said they participated in along with others. With the high participation of children in extracurricular activities as reported in this study, it is easy to understand why there was high school attendance among the children despite the fact that a good number of them paid school fees. The finding that children of leprosy patients had high school attendance is at variance with that of four different studies $^{10,11,13,14}$ which reported low school attendance for children of leprosy patients because of discrimination.

As expected, a good proportion of the children expressed that life in the settlements could be boring for them. In their opinion, they wished to live somewhere else other than the settlement, thus indicating the children's desire to fully integrate and enjoy social services with others in the society. The finding that children of leprosy patients wished to live somewhere else other than the settlement agrees with other reports ${ }^{2,}$ that children of leprosy patients prefer to relocate outside the settlements so as to freely attend social functions like others. Thus, efforts should be geared toward ensuring that children of leprosy patients as well as their parents, on discharge, are reunited with their relations outside the settlement. This will help reduce the population of leprosy patients and their children resident in settlements in Nigeria.

Again, a good number of the children of leprosy patients studied had excellent ideas of what their career goals should be, suggesting that the children had high aspirations to achieve greater goals like others in the society. As such, they deserve to be encouraged to realize their goals. One way of achieving this is by providing them with opportunities for free education and improved health care services. These reasons are necessary for policy makers and others to note as guide while planning services that would target children of leprosy patients.

\section{Recommendations}

\section{Free education}

Free education should be provided to children of leprosy patients. This would encourage regular school attendance, reduction in activities children of leprosy patients take to augment family resources. Expecting leprosy patients with no meaningful means of livelihood except peasant farming, to pay their children's school fees would increase their financial burden thereby, deny their children the opportunity of realizing their life goals.

\section{Inclusion in health care prevention programmes}

Children of leprosy patients should be included in national health care prevention programmes like immunization services, HIV/AIDS prevention programmes, family planning services and others. This recommendation is made based on the finding that little or no health care prevention programmes are accessible to children of leprosy. The number of mature boys and girls resident in the settlements as well as the number of females found pregnant and/or nursing babies during the study calls for family planning services. These services if provided to the children would reduce their risky sexual practices thereby protect them from sexually transmitted infections including HIV. This calls for governments (local, state and federal) to enunciate policies that would include the children of leprosy patients in health planning schemes.

\section{Prophylactic treatment}

Considering the number of children infected with leprosy in the settlements, there is needed to protect these children against all forms of infection including leprosy. This is in line with the recommendations of the World Health Organization, that prophylaxis should be given to individuals exposed to leprosy infection.

\section{Free health care services}

Free health care services should be extended to the children of leprosy patients. This will help to improve their health seeking behavior and reduce the tendency of self-medication. This recommendation is made based on the number of children who could not seek treatment because of inability of their parents to pay for cost of treatment.

\section{Health education}

Health education should be provided in the settlements. This will highlight the benefits of living in a hygienic environment so as to protect the children from infections. A health education team can be formed and may be part of the primary school system and/or health care system. The team should have a well-planned program to cover the needs of the leprosy patients and their environments.

\section{Periodic review of services available to children of leprosy patients}

There should be periodic review of services available to children of leprosy patients in Nigeria. This will enable researchers to note the extent to which governments (local, state and federal) include the children of leprosy patients in their health and other welfare programmes during national budgets. Also the research findings should be made available to stakeholders in leprosy control programmes (leprosy settlement authorities, interested persons, religious groups, NGOs, and governments for their information and guidance in their commitments to leprosy control. 


\section{Acknowledgment}

We sincerely appreciate the academic contributions of $\mathrm{Dr}$ F.O. Omokhodion, Dr E.A. Olumide, Professors J.A. Adeniyi, O. Oladepo, and A. Oyemade. We also thank the Directors of the three settlements, the three Leprologists in Ministries of Health in charge of the settlements, and the health workers for their informed consent. We are grateful to the leprosy patients for their assistance in making their children easily available.

\section{References}

1. Brown JAK. Leprosy folk-lore in Southern Nigeria. Lepr Rev. 1937;8:157-160.

2. Chukwu JN, Ekekezie UM. The leprosy centre, Uzuakoli, 1932-1992. Production Commercial Limited, Owerri, 1992.

3. Smith WCS, Jesudasan K. The elimination of leprosy and prospects for rehabilitation. Lancet. 1993;341:89-90.

4. Oyemade A, Olugbile A. Barriers to the rehabilitation of the handicapped in Nigeria. Public Health, London. 1981;95:82-86.

5. Lever P, Bijlmakers L, Zwanikken P, Saunderson R. Health systems research in leprosy control. What contributions can it make? Lepr Rev. 1998;69:122-127.

6. Hogeweq M, Faber WR. Progression of eye lesions in leprosy: ten years follow up study in the Netherlands. Int J Lepr Other Mycobact Dis. 1991;59:392-397.

7. Cull JC, Hardy RE. Understanding the psychological aspects of disability in understanding disability for social and rehabilitation services, Illinois. Thomas, Springfield 1973.

8. Dwivedi MP. A study of medico-social problems of cured leprosy cases in the Pandri village of Raipur district. Journal of Leprosy in India. 1974;46:245-252.
9. Macaden VP. An introduction to community based rehabilitation in leprosy. Partners Magazine for Paramedical. 1996;30:3-5.

10. Rotherge A. Leprosy: psychosocial-somatic phenomenon. Int J Lepr Other Mycobact Dis. 1975;43:62-63.

11. Rao PS, Kumar J, Mani K, Melville C. Impact of MDT on incidence rates of leprosy among household contacts. Int J Lepr Other Mycobact Dis. 1989;57:647-651.

12. Becker G, Arnold R. Stigma as a social and cultural construct. In: Ainlay SC, Becker G, Coloman LM. The dilemma of difference - a multidisciplinary view of stigma. Plerum Publishers, New York, 1986; 39-57.

13. Oliveira $\mathrm{MH}$. The effects of leprosy on men and women: A gender study. Gender Tropical Diseases. 1997;4:1-9.

14. Pimpawun B. 'Khi Thut.' The disease of social loathing: an anthropological study of the stigma of leprosy in rural North East Thailand. Social and Economic Research Project Report. 1994;16:145.

15. Hewett RM. The emotionally disturbed child in the classroom. Allyn and Bacon, Boston, 1968.

16. Levi L. Society, stress and disease: the psychosocial environment and psychosomatic diseases. Oxford University Press, London, 1971.

17. Selvapandian AJ, Richard J, Wilson JF. Comparisons of attitude to leprosy between rural and urban dwellers. Journal of Leprosy in India. 1972;44:69-70.

18. Hasselblad OW. Psycho-social aspects of leprosy. PAHO Bulletin. 1974;8:283-288.

19. WHO guide to leprosy control. World Health Organization, Geneva, 1980.

20. WHO expert committee on leprosy sixth report. Technical Report Series 768, World Health Organization, Geneva, 1988. 